\title{
Evaluation of Trichoderma spp. Isolates in Cocoa Seed Treatment and Seedling Production
}

\author{
Willian Nogueira de Sousa ${ }^{1, * \mathbb{D}}$, Nayane Fonseca Brito ${ }^{2}$, Cristina Aledi Felsemburgh ${ }^{2}$, Thiago Almeida Vieira ${ }^{2} \mathbb{D}$ \\ and Denise Castro Lustosa ${ }^{2, *}$ \\ 1 Altamira City Hall, Altamira 68371-456, Brazil \\ 2 Institute of Biodiversity and Forests, Federal University of Western Pará, Santarém 68040-255, Brazil; \\ nayanebrito4@gmail.com (N.F.B.); crisalefel@gmail.com (C.A.F.); thiago.vieira@ufopa.edu.br (T.A.V.) \\ * Correspondence: wnsagro@gmail.com (W.N.d.S.); denise.lustosa@ufopa.edu.br (D.C.L.)
}

check for

updates

Citation: de Sousa, W.N.; Brito, N.F.; Felsemburgh, C.A.; Vieira, T.A.;

Lustosa, D.C. Evaluation of

Trichoderma spp. Isolates in Cocoa

Seed Treatment and Seedling

Production. Plants 2021, 10, 1964.

https://doi.org/10.3390/

plants10091964

Academic Editor:

Mariateresa Cardarelli

and Sheridan L. Woo

Received: 1 September 2021

Accepted: 17 September 2021

Published: 20 September 2021

Publisher's Note: MDPI stays neutral with regard to jurisdictional claims in published maps and institutional affiliations.

Copyright: (c) 2021 by the authors. Licensee MDPI, Basel, Switzerland. This article is an open access article distributed under the terms and conditions of the Creative Commons Attribution (CC BY) license (https:// creativecommons.org/licenses/by/ $4.0 /)$.

\begin{abstract}
Isolates of Trichoderma spp., a soil fungus, has been used to control diseases and promote plant growth, reducing the use of chemicals in the production of seedlings of different plant species. We evaluated the effect of some Trichoderma spp. isolates on seed treatment and seedling production of Theobroma cacao. Five isolates from the Amazon region were tested. In laboratory, the following variables were evaluated for seed treatments: germination, germination speed index, radicle and hypocotyl lengths, and fungi incidence. In nursery, the following forms of application were tested: via seeds; in the substrate at pre-planting; monthly in post-planting substrate, and also their combination. The following was evaluated: height, diameter, number of leaves, root length, leaf area, and shoot dry mass and root system. Inoculation with Trichoderma increased the length of the radicle and hypocotyl and showed no fungi in the seeds. In seedlings, some treatments increased height and plant root dry mass. The use of Trichoderma was beneficial for seeds and appeared favorable for T. cacao production.
\end{abstract}

Keywords: biocontrol; Theobroma cacao; biostimulant; germination; growth promotion

\section{Introduction}

Recently, an increase in the use of biological agents in agriculture has been observed [1,2], which consists of the application of microorganisms or their metabolites to protect seeds and promote germination and plant growth and management of different pathogens and pests [3,4]. Among the microorganisms that can be used, several isolates of Trichoderma spp. showed different mechanisms of action, such as antibiosis, mycoparasitism, competition, resistance induction, and growth promotion, in addition to solubilization of nutrients [5-8]. These properties provide productive and economic gains in the process of growing important crops.

Cocoa (Theobroma cacao L.) is a species of great economic and social importance globally. Worldwide, cocoa-producing areas occupy approximately 6.7 million hectares, with an estimated production of 4.7 million tons, generating a revenue of approximately 8.6 billion dollars per year [9]. In Brazil, this crop gained prominence with the expansion of chocolate consumption. Its cultivation represents a good example for composing agroforestry systems, as it can be cultivated under the shade of the thinned native forest ("cabruca" system) in association with other species, without the need of deforestation [10].

Pests and diseases affect cocoa crops strongly, constituting a major problem for producers [11]. The use of agrochemicals, applied from seed treatment and seedling preparation through cultivation to post harvest, has caused serious problems of environmental contamination, and therefore, products in favor of sustainable agriculture have been studied and developed.

The use of Trichoderma spp. on T. cacao has mainly been studied for disease control [12]. However, this fungus can also promote the development of seedlings and root systems in addition to delaying drought responses when plants are subjected to water stress [13]. 
Thus, research is important to identify Trichoderma isolates that are efficient and adapted to the environmental conditions of the producing region, which can be used for treating seeds and seedlings and in the development of cultivated plants.

The sanitary quality of seeds is essential for the production of healthy and vigorous seedlings [14] and for the production of quality, vigorous, and pest and disease-free seedlings with good adaptation and field growth [15]. Thus, the treatment of seeds and seedlings with Trichoderma spp. is an alternative that can generate good results in different plant species, as it is considered sustainable.

Our hypothesis was that the application of Trichoderma stimulates the germination of cacao seeds and the initial growth of seedlings, reducing the time the plants remain in the nursery, ensuring quality seedlings. In this article, we evaluate the effect of five Trichoderma isolates in different application modes on seed treatment and development of T. cacao seedlings.

\section{Results}

\subsection{Trichoderma Effect on T. cacao Seed Germination}

There was a significant difference for the radicle and hypocotyl length and the incidence of fungi. In all treatments, germination was greater than 95\% (Table 1). Trichoderma did not influence germination speed compared to control.

Table 1. Germination and germination speed index (SG) and radicle and hypocotyl lengths of Theobroma cacao seeds treated or not with different Trichoderma isolates. Incidence of fungi represent the $\%$ of seed contaminated with other fungi.

\begin{tabular}{cccccccccc}
\hline Treatment & $\begin{array}{c}\text { Germination } \\
(\mathbf{\%})\end{array}$ & SG & \multicolumn{2}{c}{$\begin{array}{c}\text { Radicle } \\
(\mathbf{c m})\end{array}$} & $\begin{array}{c}\text { Hypocotyl } \\
\text { (cm) }\end{array}$ & $\begin{array}{c}\text { Incidence of } \\
\text { Fungi (\%) }\end{array}$ \\
\hline Control & 97.0 & $\mathrm{ab}$ & 58.3 & $\mathrm{a}$ & 1.2 & $\mathrm{c}$ & 1.3 & $\mathrm{c}$ & 26.5 \\
Trichoderma sp. Tc & 98.0 & $\mathrm{a}$ & 61.7 & $\mathrm{a}$ & 4.3 & $\mathrm{a}$ & 2.6 & $\mathrm{a}$ & 0.0 \\
Trichoderma sp. Tce & 97.5 & $\mathrm{~b}$ & 61.7 & $\mathrm{a}$ & 4.2 & $\mathrm{a}$ & 2.2 & $\mathrm{ab}$ & 0.0 \\
T. asperellum Tam01 & 96.5 & $\mathrm{ab}$ & 61.9 & $\mathrm{a}$ & 4.1 & $\mathrm{a}$ & 2.3 & $\mathrm{ab}$ & 0.0 \\
T. asperellum Tam02 & 98.0 & $\mathrm{a}$ & 54.4 & $\mathrm{a}$ & 3.2 & $\mathrm{~b}$ & 1.6 & $\mathrm{bc}$ & 0.0 \\
T. asperellum Tam03 & 95.0 & $\mathrm{~b}$ & 52.6 & $\mathrm{a}$ & 3.1 & $\mathrm{~b}$ & 2.4 & $\mathrm{a}$ & 0.0 \\
\hline $\mathrm{CV}(\%)$ & 1.3 & & 7.7 & & 9.8 & & 15.8 & & \\
\hline
\end{tabular}

$\overline{\mathrm{CV}}$, coefficient of variation; means followed by the same letters in the columns do not differ from each other by the Tukey test $(p \leq 0.05)$.

All Trichoderma isolates increased radicle length compared to the control (Table 1, Figure 1), ranging from 1.9 to $3.1 \mathrm{~cm}$, corresponding to an increase from $158 \%$ to $258.3 \%$, respectively. For the length of the hypocotyl, there was a significant difference except for the seeds treated with isolate Tam02, which did not differ from the control (Table 1). The increase in hypocotyl ranged from 0.9 to $1.3 \mathrm{~cm}$, representing an increase from $69.2 \%$ to $100 \%$ for the Tce and Tc isolates, respectively.

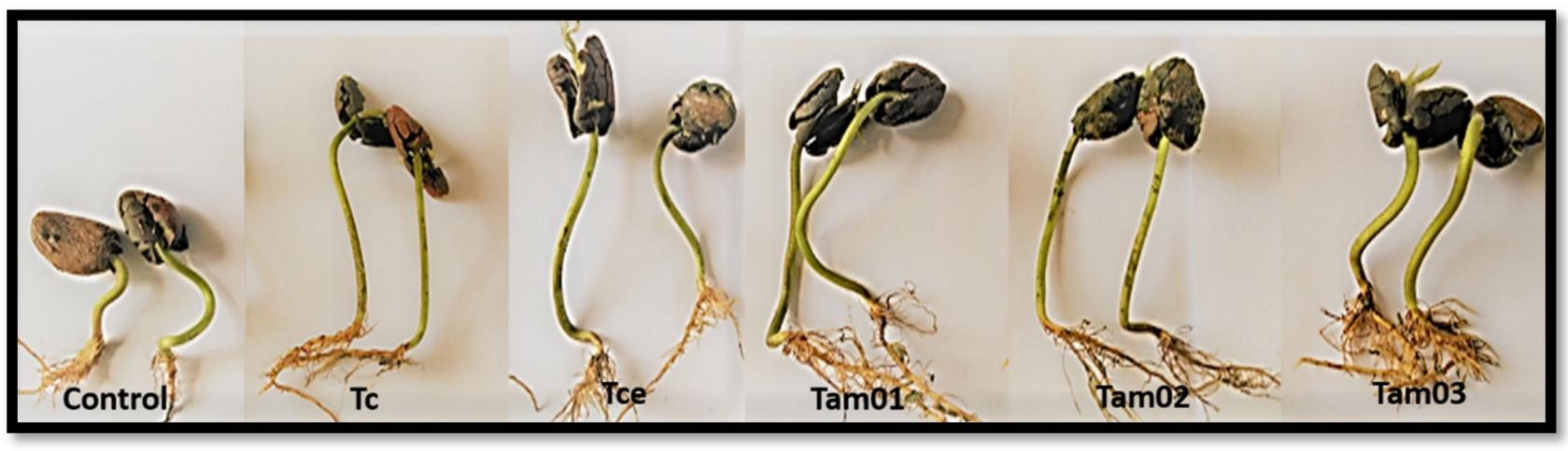

Figure 1. Radicle and hypocotyl lengths of cocoa seedlings resulting from seeds treated or not with different Trichoderma spp. isolates. 
The incidence of other fungi was observed only in the control treatment, with $26.5 \%$ of contaminated seeds (Table 1). They did not affect, however, the germination of seeds.

\subsection{Trichoderma spp. in the Production of T. cacao Seedlings}

A significant difference for the height and root dry mass of seedlings, at three and six months, was observed (Table 2).

Two Trichoderma isolates increased plant height compared to the control. They were T. asperellum Tam01, applied monthly to the substrate after planting in the two evaluation periods, and T. asperellum Tam02, applied to the seeds in the evaluation at six months only (Table 2, Figure 2). The increase in height provided by Tam01 achieved $4.4 \mathrm{~cm}$ at three months and $5.8 \mathrm{~cm}$ at six months, corresponding to an increase by $17.2 \%$ and $20.4 \%$, respectively. For Tam02 applied to seeds, the increase in height was $5.9 \mathrm{~cm}(20.7 \%)$ when compared to the control.

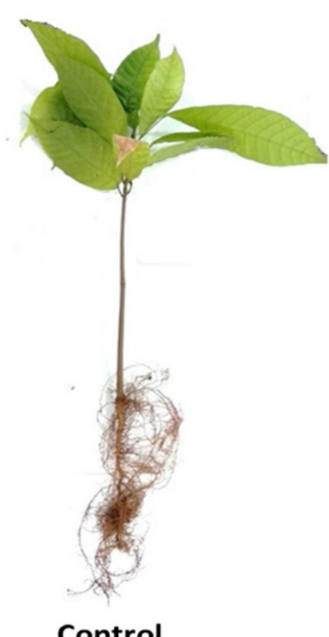

Control

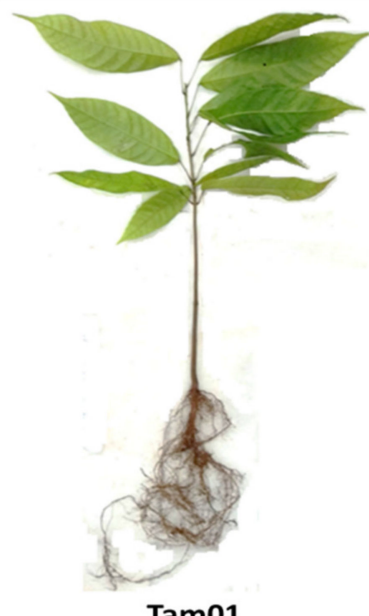

Monthly Applications

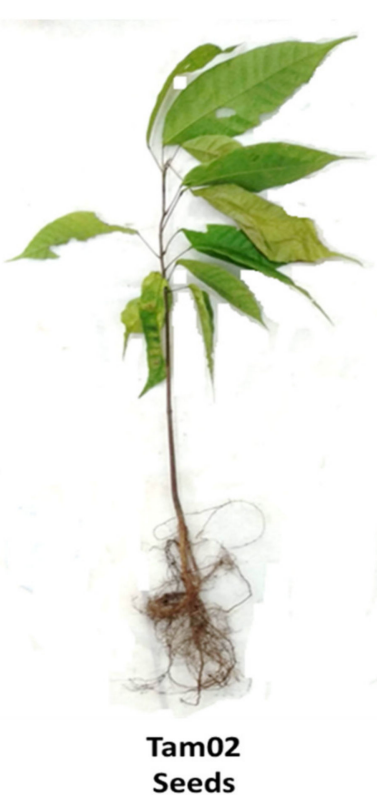

Figure 2. Cocoa seedlings with and without application of Trichoderma asperellum, six months after planting.

Tam01 also showed an increase in root dry mass of plants in the triple combination of application modes (seeds + substrate pre-planting + monthly applications in the substrate post planting) (Table 2), with an increase of $1.1 \mathrm{~g}$ in relation to the control, corresponding to a $64 \%$ increment.

When comparing the treatments, there was a significant difference for the interaction between (Trichoderma isolates $\times$ application modes) only for the plant height at six months after planting. In the mode of application via seeds, the height of seedlings treated with Tam02 was greater than those that received the application of isolates Tc and Tam03. In the monthly applications in the post-planting substrate, a difference was observed only between Tam01 and Tam02, with mean height values of $34.2 \mathrm{~cm}$ and $29.4 \mathrm{~cm}$, respectively (Table 3). 


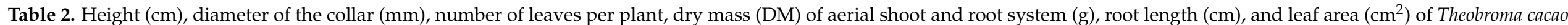
seedlings submitted to different application modes and Trichoderma spp. isolates.

\begin{tabular}{|c|c|c|c|c|c|c|c|c|c|c|}
\hline \multirow{2}{*}{ Treatments } & \multicolumn{2}{|c|}{ Height } & \multicolumn{2}{|c|}{ Collar Diameter } & \multicolumn{2}{|c|}{ Number of Leaves } & \multirow{2}{*}{$\begin{array}{c}\text { Aerial } \\
\text { DM }\end{array}$} & \multirow{2}{*}{$\begin{array}{l}\text { Root } \\
\text { DM }\end{array}$} & \multirow{2}{*}{ Root Length } & \multirow{2}{*}{ Leaf Area } \\
\hline & 3rd month & 6th month & 3rd month & 6th month & 3rd month & 6th month & & & & \\
\hline Tc applied to seeds & $26.0^{\mathrm{ns}}$ & $27.9^{\mathrm{ns}}$ & $5.4^{\mathrm{ns}}$ & $6.2^{\mathrm{ns}}$ & $7.7^{\mathrm{ns}}$ & $9.3^{\mathrm{ns}}$ & $2.8^{\mathrm{ns}}$ & $1.9^{\mathrm{ns}}$ & $49.1^{\mathrm{ns}}$ & $613.1^{\mathrm{ns}}$ \\
\hline Tc applied to pre-planting substrate & $24.9^{\mathrm{ns}}$ & $29.6^{\mathrm{ns}}$ & $5.2^{\mathrm{ns}}$ & $6.4^{\mathrm{ns}}$ & $7.5^{\mathrm{ns}}$ & $10.6^{\mathrm{ns}}$ & $3.3^{\mathrm{ns}}$ & $2.0^{\mathrm{ns}}$ & $54.4^{\mathrm{ns}}$ & $437.7^{\mathrm{ns}}$ \\
\hline $\begin{array}{l}\text { Tc applied monthly to post-planting } \\
\text { substrate }\end{array}$ & $25.7^{\mathrm{ns}}$ & $30.3^{\mathrm{ns}}$ & $5.7^{\mathrm{ns}}$ & $6.5^{\mathrm{ns}}$ & $7.8^{\mathrm{ns}}$ & $12.7^{\mathrm{ns}}$ & $4.1^{\mathrm{ns}}$ & $2.2^{\mathrm{ns}}$ & $47.0^{\mathrm{ns}}$ & $613.1^{\mathrm{ns}}$ \\
\hline Tc seeds + substrate + monthly & $28.2^{\mathrm{ns}}$ & $32.3^{\text {ns }}$ & $5.5^{\mathrm{ns}}$ & $6.3^{\mathrm{ns}}$ & $8.8^{\mathrm{ns}}$ & $11.2^{\mathrm{ns}}$ & $3.3^{\mathrm{ns}}$ & $2.1^{\mathrm{ns}}$ & $54.9^{\mathrm{ns}}$ & $448.7^{\mathrm{ns}}$ \\
\hline Tce applied to seeds & $27.0^{\mathrm{ns}}$ & $30.4^{\mathrm{ns}}$ & $5.2^{\mathrm{ns}}$ & $6.4^{\mathrm{ns}}$ & $7.2^{\mathrm{ns}}$ & $10.3^{\mathrm{ns}}$ & $3.6^{\mathrm{ns}}$ & $2.3^{\mathrm{ns}}$ & $51.1^{\mathrm{ns}}$ & $551.8^{\mathrm{ns}}$ \\
\hline Tce applied to pre-planting substrate & $26.5^{\mathrm{ns}}$ & $31.2^{\mathrm{ns}}$ & $5.2^{\mathrm{ns}}$ & $6.2^{\mathrm{ns}}$ & $8.0^{\mathrm{ns}}$ & $10.2^{\mathrm{ns}}$ & $3.0^{\mathrm{ns}}$ & $1.8^{\mathrm{ns}}$ & $51.7^{\mathrm{ns}}$ & $539.1^{\mathrm{ns}}$ \\
\hline Tce seeds + substrate + monthly & $26.0^{\mathrm{ns}}$ & $31.1^{\mathrm{ns}}$ & $5.4^{\mathrm{ns}}$ & $6.3^{\mathrm{ns}}$ & $9.0^{\mathrm{ns}}$ & $10.5^{\mathrm{ns}}$ & $3.6^{\mathrm{ns}}$ & $2.3^{\mathrm{ns}}$ & $52.8^{\mathrm{ns}}$ & $413.6^{\mathrm{ns}}$ \\
\hline Tam01 applied to seeds & $26.9^{\mathrm{ns}}$ & $32.3^{\text {ns }}$ & $5.4^{\mathrm{ns}}$ & $6.7^{\mathrm{ns}}$ & $8.5^{\mathrm{ns}}$ & $11.0^{\mathrm{ns}}$ & $3.6^{\mathrm{ns}}$ & $1.9^{\mathrm{ns}}$ & $52.3^{\mathrm{ns}}$ & $514.1^{\mathrm{ns}}$ \\
\hline $\begin{array}{l}\text { Tam01 applied to pre-planting } \\
\text { substrate }\end{array}$ & $26.8^{\mathrm{ns}}$ & $29.8^{\mathrm{ns}}$ & $5.1^{\mathrm{ns}}$ & $6.0^{\mathrm{ns}}$ & $8.0^{\mathrm{ns}}$ & $10.6^{\mathrm{ns}}$ & $2.8^{\mathrm{ns}}$ & $1.9^{\mathrm{ns}}$ & $53.4^{\mathrm{ns}}$ & $380.6^{\mathrm{ns}}$ \\
\hline $\begin{array}{l}\text { Tam01 applied monthly to } \\
\text { post-planting substrate }\end{array}$ & $30.0 *$ & $34.2 *$ & $5.0^{\mathrm{ns}}$ & $6.5^{\mathrm{ns}}$ & $8.7^{\mathrm{ns}}$ & $11.8^{\mathrm{ns}}$ & $3.8^{\mathrm{ns}}$ & $1.8^{\mathrm{ns}}$ & $50.0^{\mathrm{ns}}$ & $585.5^{\mathrm{ns}}$ \\
\hline Tam01 seeds + substrate + monthly & $27.6^{\mathrm{ns}}$ & $31.5^{\mathrm{ns}}$ & $5.8^{\mathrm{ns}}$ & $6.6^{\mathrm{ns}}$ & $9.5^{\mathrm{ns}}$ & $11.1^{\mathrm{ns}}$ & $3.4^{\mathrm{ns}}$ & $2.8^{*}$ & $55.2^{\mathrm{ns}}$ & $559.2^{\mathrm{ns}}$ \\
\hline Tam02 applied to seeds & $27.9^{\mathrm{ns}}$ & $34.3 *$ & $5.2^{\mathrm{ns}}$ & $6.3^{\mathrm{ns}}$ & $8.8^{\mathrm{ns}}$ & $11.2^{\mathrm{ns}}$ & $3.4^{\mathrm{ns}}$ & $1.7^{\mathrm{ns}}$ & $59.6^{\mathrm{ns}}$ & $529.9^{\mathrm{ns}}$ \\
\hline $\begin{array}{l}\text { Tam02 applied monthly to } \\
\text { post-planting substrate }\end{array}$ & $27.3^{\mathrm{ns}}$ & $29.4^{\mathrm{ns}}$ & $5.1^{\mathrm{ns}}$ & $6.1^{\mathrm{ns}}$ & $7.8^{\mathrm{ns}}$ & $9.2^{\mathrm{ns}}$ & $2.9^{\mathrm{ns}}$ & $1.6^{\mathrm{ns}}$ & $53.1^{\mathrm{ns}}$ & $442.2^{\mathrm{ns}}$ \\
\hline Tam02 seeds + substrate + monthly & $28.8^{\mathrm{ns}}$ & $32.4^{\mathrm{ns}}$ & $5.5^{\mathrm{ns}}$ & $6.5^{\mathrm{ns}}$ & $8.8^{\mathrm{ns}}$ & $9.6^{\mathrm{ns}}$ & $3.5^{\mathrm{ns}}$ & $2.1^{\mathrm{ns}}$ & $56.1^{\mathrm{ns}}$ & $464.0^{\mathrm{ns}}$ \\
\hline Tam03 applied to seeds & $25.8^{\mathrm{ns}}$ & $28.3^{\mathrm{ns}}$ & $5.3^{\text {ns }}$ & $6.2^{\mathrm{ns}}$ & $7.8^{\mathrm{ns}}$ & $9.6^{\mathrm{ns}}$ & $3.2^{\mathrm{ns}}$ & $2.0^{\mathrm{ns}}$ & $43.6^{\mathrm{ns}}$ & $494.4^{\mathrm{ns}}$ \\
\hline $\begin{array}{l}\text { Tam03 applied to pre-planting } \\
\text { substrate }\end{array}$ & $26.5^{\mathrm{ns}}$ & $30.2^{\mathrm{ns}}$ & $5.3^{\text {ns }}$ & $6.3^{\mathrm{ns}}$ & $7.2^{\mathrm{ns}}$ & $10.3^{\mathrm{ns}}$ & $2.8^{\mathrm{ns}}$ & $1.5^{\mathrm{ns}}$ & $53.2^{\mathrm{ns}}$ & $425.4^{\mathrm{ns}}$ \\
\hline $\begin{array}{l}\text { Tam03 applied monthly to } \\
\text { post-planting substrate }\end{array}$ & $27.0^{\mathrm{ns}}$ & $29.9^{\mathrm{ns}}$ & $5.2^{\mathrm{ns}}$ & $6.0^{\mathrm{ns}}$ & $7.7^{\mathrm{ns}}$ & $10.7^{\mathrm{ns}}$ & $3.3^{\mathrm{ns}}$ & $1.7^{\mathrm{ns}}$ & $51.1^{\mathrm{ns}}$ & $422.8^{\mathrm{ns}}$ \\
\hline Tam03 seeds + substrate + monthly & $26.8^{\mathrm{ns}}$ & $31.1^{\mathrm{ns}}$ & $5.5^{\mathrm{ns}}$ & $6.4^{\mathrm{ns}}$ & $7.8^{\mathrm{ns}}$ & $9.2^{\mathrm{ns}}$ & $3.1^{\mathrm{ns}}$ & $1.9^{\mathrm{ns}}$ & $56.4^{\mathrm{ns}}$ & $385.1^{\mathrm{ns}}$ \\
\hline Control & 25.6 & 28.4 & 5.1 & 6.0 & 7.6 & 10.7 & 3.4 & 1.7 & 51.5 & 484.1 \\
\hline Coefficient of Variation (\%) & 9.9 & 10.5 & 10.4 & 11.4 & 18.6 & 22.1 & 28.0 & 31.9 & 23.2 & 20.7 \\
\hline
\end{tabular}

* Significant; ns, not significant; by Dunnett test $(p<0.05)$. Tc, Trichoderma sp.; Tce, Trichoderma sp.; Tam01, T. asperellum; Tam02, T. asperellum; Tam03, T. asperellum. 
Table 3. Height of Theobroma cacao seedlings in relation to different modes of application modes of Trichoderma spp., six months after planting.

\begin{tabular}{|c|c|c|c|c|c|c|c|}
\hline \multirow{3}{*}{$\begin{array}{c}\text { Modes of Application } \\
\text { Seeds }^{1}\end{array}$} & \multicolumn{7}{|c|}{ Trichoderma Isolates } \\
\hline & Tc & \multicolumn{2}{|c|}{ Tce } & \multicolumn{2}{|c|}{ Tam01 } & Tam02 & Tam03 \\
\hline & $27.9 \mathrm{bB}$ & 30.3 & $\mathrm{aAB}$ & 32.3 & $\mathrm{abAB}$ & 34.3 & 28.2 \\
\hline Substrate $^{2}$ & $29.5 \mathrm{abA}$ & 31.2 & $\mathrm{aA}$ & 29.7 & $\mathrm{bA}$ & 31.3 & 30.2 \\
\hline Monthly Aplication ${ }^{3}$ & $30.3 \mathrm{abAB}$ & 30.6 & $\mathrm{aAB}$ & 34.2 & $\mathrm{aA}$ & 29.4 & 29.9 \\
\hline Seed + Subs. + Mon.Ap. ${ }^{4}$ & $32.3 \mathrm{aA}$ & 31.0 & $\mathrm{aA}$ & 31.5 & $\mathrm{abA}$ & 32.4 & 31.1 \\
\hline
\end{tabular}

Means followed by the same lowercase letters in the columns and the same uppercase letters in the rows do not differ by Tukey's test $(p \leq 0.05) .{ }^{1}=$ Trichoderma application to seeds; ${ }^{2}=$ application of Trichoderma in the substrate at pre-planting; ${ }^{3}=$ monthly application of Trichoderma in the pos-planting substrate; ${ }^{4}=$ Trichoderma applied seeds + application in the substrate at pre-planting + monthly application in the substrate post planting.

\section{Discussion}

Biological agents applied to seeds and seedlings are important components of sustainable agriculture strategies. In this study, Trichoderma spp. natives of the Amazon region were used in cocoa, a naturally occurring species of this biome.

Although Trichoderma isolates did not increase germination parameters compared to the control, they positively affected seedlings growth. Data indicate a healthy condition of the seeds used, showing an average germination close to that of newly harvested fruits of this species, which can reach $100 \%$ [16]. This was likely due to storage lipids that act as carbon and energy reserves for embryos to germinate, favoring high germination rates [17]. On the opposite, the storage of seeds for long periods of time affects germination, as seeds do not tolerate dehydration or low temperatures [18].

Biological treatment positively influenced other variables related to cocoa seed germination, such as radicle and hypocotyl length. Data showed that the greatest increase in radicle length was 3.6-times higher than the control and twice the hypocotyl length. Indoleacetic acid (IAA) appears as a possible effector in this interaction. Root exudates are sources of the amino acid L-tryptophan, a precursor for IAA biosynthesis by the rhizosphere microbiota $[19,20]$. IAA regulates several stages of plant growth and development, such as cell elongation and division, tissue differentiation, and apical dominance [21]. In addition to auxins, cytokinin produced by microorganisms promote plant growth and cell division [22]. The effects observed on shoot growth may be hence related to the production active effectors translocated from the roots to the shoot and induced by auxin-producing microorganisms that thus stimulate the root system [23]. The production of auxins by Trichoderma spp. has already been shown $[24,25]$.

There are several reports indicating a biostimulation effect induced by Trichoderma spp. Seeds of Theobroma grandiflorum, a relative of cocoa, treated with isolates of T. asperellum showed an increased length of the radicle in the seedlings but no effect on germination parameters [26]. Moreover, the incidence of fungi was observed only in untreated seeds, demonstrating the efficiency of Trichoderma in controlling fungi naturally occurring in cocoa seeds. Similarly, in T. grandiflorum, no fungi were observed in seeds treated with the same Trichoderma isolates herein evaluated [26].

The absence of harmful fungi in seeds is important for developing of healthy seedlings and for their survival in the field. Among seeds colonizing fungi, species of Aspergillus and Penicillium have been reported as potential producers of mycotoxins in cocoa beans [27]. Seed treatments are important to reduce or eliminate microorganisms that can harm the seeds and affect the initial development of seedlings. Additionally, since Trichoderma spp. includes important biocontrol agents, biological treatments appear useful to protect the young plants from the attack of pathogens already present in the soil.

Identifying the ideal conditions for seed germination is an important factor to ensure uniform production of quality seedlings and for the establishment of a standard in the field 
production [28]. In the nursery assay, only two Trichoderma isolates applied in seeds and in the post-planting substrate influenced height (Tam01 and Tam02) and root dry mass (Tam01). Differences in isolates efficiency may be related to different mechanisms of action in plant growth promotion and biological control that may vary according to environmental conditions (substrate, nutrients, other microorganisms), species, or association with the host plant [29].

Growth promotion is not a general feature for all Trichoderma spp., as different effects on plants have been observed. In addition, promotion variability may be related to and influenced by environmental factors [30,31]. In a collection from Colombia, $60 \%$ of Trichoderma strains produced IAA derivatives in vitro, but only $18 \%$ showed plant growth effects on beans [32]. In addition to this, auxins and volatile organic compounds have been described as growth-promoting inducers in fungi, including Trichoderma [33]. Evaluation of Trichoderma spp. isolates in Jatropha curcas and Ricinus communis showed negative effects for some isolates on the diameter, number of leaves, and dry mass of the aerial part and root system of plants [34]. A promotion effect on root dry mass and height were instead reported in Gochnatia polymorpha plants treated with Trichoderma harzianum [29]. Seedlings of Handroanthus serratifolius (yellow ipe) treated with Trichoderma showed increased height, stem diameter, number of leaves, and root dry mass compared to the control [35]. Increased height of plants treated with Trichoderma was also found in Khaya ivorensis and Eucalyptus camaldulensis, with increased number of leaves and higher shoot and root dry mass, and Pinus radiata [36-38].

The $64 \%$ increase in root dry mass observed in the treatment with Trichoderma Tam01 isolate and applied in a triple combination (seeds + pre-planting substrate + monthly applications in post-planting substrate) is a promising result. The plant's investment in root growth is one of the main benefits attributed to microorganisms that produce IAA. For young plants, the growth and establishment of roots is essential, as the increase in root biomass promotes adherence to the substrate and greater absorption of water and nutrients. These effects increase nutrients accumulation and cell multiplication through the production of hormones and other metabolites, consequently increasing the chances of survival in the field [39-46].

The application of Trichoderma Tam01 isolate in the pre-planting substrate combined with applications in the post-planting substrate also positively influenced the development of Euterpe oleracea seedlings [2]. The use of Trichoderma in the pre-planting substrate increased the height, stem diameter, and number of leaves of E. schomburgkii seedlings [47]. Trichoderma spp. used in seeds or in combination with substrate application were also effective on seedlings of Khaya ivorensis [36]. In seedlings of Parapiptadenia rigida, the application of Trichoderma via seeds showed the greatest increase in plant height [48].

Trichoderma spp. have potential for application with several purposes, such as biological control of plant diseases, production of enzymes for industries, and other fundamental aspects, such as increasing the efficiency of nitrogen use, promoting the development of plants, as well as productivity and alleviating the impacts of salt stresses [49].

\section{Materials and Methods}

The research was registered in the National System for the Management of Genetic Heritage and Associated Traditional Knowledge (SISGEN-Brazil) under protocol A67256B. The evaluation of Trichoderma isolates on T. cacao was performed in two tests: in the laboratory, to evaluate the effect of treatment on germination and initial development of the seedlings, and in a nursery, to assess the effect on seedling development.

\subsection{Obtaining and Mass Production of Trichoderma spp. Isolates}

Five Trichoderma isolates were used: three belonging to the species Trichoderma asperellum (Tam01, Tam02, and Tam03) hailing from rhizospheric soil of forest species in reforested areas and native forests from the Urucu Base, Coari, and two species of Trichoderma sp. (Tc and Tce) from soils of agroforestry systems with Curauá (Ananas erectifolius L.B.Smith) and 
Cumaru (Dipteryx odorata (Aubl.) Willd.), from São Pedro Community region of Eixo Forte, Santarém, all from Brazilian Amazonia. In this research, we prioritized using Trichoderma isolates from the Amazonia, as they are adapted to the conditions of this region. All isolates are stored in the Micoteca of the Phytopathology Laboratory of the Federal University of Western Pará-Ufopa.

Trichoderma isolates were previously grown in Petri dishes containing potato-dextroseagar (PDA) culture medium and mass-produced in parboiled rice for the preparation of suspensions used in germination tests and seedling production. The preparation of the suspension of each isolate occurred at the time of setting up the experiment, using distilled and sterilized water.

\subsection{Trichoderma Effect on Germination of T. cacao Seeds}

The experiment was performed at the Phytopathology Laboratory of the Ufopa. For treating T. cacao seeds, fungal suspensions were prepared with each Trichoderma isolate at a concentration of $1 \times 10^{8}$ conidia. $\mathrm{mL}^{-1}$, in which the seeds were immersed for $24 \mathrm{~h}$ [2]. The concentration used was based on the recommendation to use Trichoderma in cocoa as a biocontrol agent [49]. The control treatment consisted of immersing the seeds only in distilled and sterilized water for the same time. After microbiolization, the seeds were then placed in plastic trays containing two layers of moistened filter paper and maintained at room temperature $\left( \pm 27^{\circ} \mathrm{C}\right)$ during the evaluation period.

The experimental design was completely randomized (CRD), with four replications containing 50 seeds each, making 1200 seeds. We evaluated: (a) germination speed index (IVG) [50]; (b) germination, counting the number of germinated seeds, and, after three stable counts, determining the percentage of germination; (c) lengths of the radicle and hypocotyl, measuring the structures with the aid of a millimeter ruler after the germination count; and (d) incidence of fungi by counting the number of seeds with the presence of fungi under a stereoscopic microscope except for Trichoderma in those treatments that received the biological treatment.

\subsection{Trichoderma spp. and Development of T. cacao Seedlings}

The trial was conducted in the Forest Seedling Nursery of the Institute of Biodiversity and Forests, Ufopa, Santarém, Pará. The average annual temperature of the city of Santarém is approximately $27.2{ }^{\circ} \mathrm{C}$, and average annual rainfall is $3109 \mathrm{~mm}$ [51].

Trichoderma isolates were tested in four application modes: (a) on seeds; (b) on the pre-planting substrate; (c) monthly in the post-planting substrate; and (d) via seeds + pre-planting substrate + monthly in post-planting substrate. Plants without Trichoderma application served as a control treatment. We tested different modes of application to select the most suitable method for plant growth and the greatest feasibility of execution by the farmer.

The planting of $T$. cacao seeds was conducted in polyethylene bags containing $1.5 \mathrm{~kg}$ of forest soil, keeping the seedlings in a nursery with $50 \%$ shading throughout the evaluation period.

For the treatments, suspensions were prepared with each of the Trichoderma isolates at a concentration of $1 \times 10^{8}$ conidia $\cdot \mathrm{mL}^{-1}$. The treatments that used the application of Trichoderma via seeds consisted of immerson in Trichoderma suspensions for $24 \mathrm{~h}$ one day before planting. Applications of Trichoderma in the pre-planting substrate were performed seven days before planting by first wetting the soil with $10 \mathrm{~mL}$ of water and then applying $10 \mathrm{~mL}$ of suspension of each isolate in the respective treatments. Monthly applications of Trichoderma isolates in the post-planting substrate began 30 days after planting, applying monthly, as in the treatment in the pre-planting substrate, until six months of seedling production. The treatments that received the combination of the three modes of application followed the same methodology adopted for each one individually. 
The trial was set up in CRD, in a factorial scheme $(4 \times 5+1)$, with four application modes $\times$ five Trichoderma isolates + a control treatment, with eight replications and one plant per replication.

We evaluated monthly: (a) plant height, by measuring the base of the stem to the apex with the aid of a millimeter ruler; (b) diameter of the collar with a digital caliper; and (c) number of leaves, by counting the total number of leaves on each plant. At the end of the experiment (six months), we evaluated: (d) length of the root system, measuring the root with a millimeter ruler; (e) leaf area, using the leaf area meter AM350 (ADC Bio Scientific Ltd., Hoddesdon, UK); and (f) dry mass of the aerial part and of the root system, weighing the parts separately after drying in an oven with forced air circulation at $60{ }^{\circ} \mathrm{C}$, for $72 \mathrm{~h}$.

\subsection{Data Analysis}

Analysis of variance (ANOVA) was performed for laboratory data, and treatment means were compared by Tukey's test $(p \leq 0.05)$. For the nursery trial, ANOVAs were performed using data obtained at three and six months, using the Dunnett test $(p \leq 0.05)$ to compare the mean of the treatments with the control and the Tukey test $(p \leq 0.05)$ to compare the means of the treatments with each other, using the statistical program Assistat ${ }^{\circledR}$ version 7.7 [52].

\section{Conclusions}

Biological treatment of Theobroma cacao seeds had a positive effect on the development of seedling structures and fungal control. The use of Trichoderma spp. isolates on the seeds is the easiest and most viable way of application for the production of cocoa seedlings. This facility and the results obtained for seeds should encourage the use of Trichoderma by cocoa farmers in the region.

The results show a possibility of producing cocoa seedlings using a sustainable technique based on the use of biostimulants for plant production. Future studies can be conducted to verify the potential of these fungi as biostimulants of seedlings and plants in the field, with benefits for the environmental and consumers' health.

Author Contributions: Conceptualization, D.C.L. and T.A.V.; methodology, W.N.d.S., N.F.B., T.A.V., D.C.L. and C.A.F.; software, D.C.L., T.A.V. and C.A.F.; validation, D.C.L., C.A.F. and T.A.V.; formal analysis, W.N.d.S., N.F.B., T.A.V., D.C.L. and C.A.F.; investigation, W.N.d.S., N.F.B., T.A.V., D.C.L. and C.A.F.; resources, D.C.L., T.A.V. and C.A.F.; data curation, W.N.d.S., N.F.B., T.A.V., D.C.L. and C.A.F.; writing — original draft preparation, W.N.d.S., N.F.B., T.A.V. and D.C.L.; writing-review and editing, D.C.L., T.A.V. and C.A.F.; visualization, D.C.L. and T.A.V.; supervision, D.C.L. and T.A.V.; project administration, D.C.L.; funding acquisition, D.C.L. and T.A.V. All authors have read and agreed to the published version of the manuscript.

Funding: This work was supported by the Institutional Scientific Initiation Scholarship Program2018 PIBIC/UFOPA and the APC was funded by PROPPIT/Federal University of Western Pará through Edital 03/2021 (Programa de Apoio à Publicação Científica em Periódicos).

Institutional Review Board Statement: Not applicable.

Informed Consent Statement: Not applicable.

Data Availability Statement: The data presented in this study are available in the text, figures, and tables.

Acknowledgments: We would like to thank the anonymous reviewers for their suggestions and constructive comments on the manuscript.

Conflicts of Interest: The authors declare no conflict of interest. 


\section{References}

1. Jorge, D.M.; Souza, C.A.V. O papel da regulamentação dos produtos de origem biológica no avanço da agroecologia e da produção orgânica no brasil. In A Política Nacional de Agroecologia e Produção Orgânica no Brasil: Uma Trajetória de Luta Pelo Desenvolvimento Rural Sustentável, 1st ed.; Sambuichi, R.H.R., Moura, I.F., Mattos, L.M., Ávila, M.L., Spínola, P.A.C., Silva, A.P.M., Eds.; IPEA: Brasília, Brasil, 2017; pp. 229-252.

2. Campos, B.F.; Araújo, A.J.C.; Felsemburgh, C.A.; Vieira, T.A.; Lustosa, D.C. Trichoderma contributes to the germination and seedling development of Açaí Palm. Agriculture 2020, 10, 456. [CrossRef]

3. Andrade-Hoyos, P.; Silva-Rojas, H.V.; Romero-Arenas, O. Endophytic Trichoderma species isolated from Persea americana and Cinnamomum verum roots reduce symptoms caused by Phytophthora cinnamomi in avocado. Plants 2020, 9, 1220. [CrossRef]

4. Silletti, S.; Di Stasio, E.; Van Oosten, M.J.; Ventorino, V.; Pepe, O.; Napolitano, M.; Marra, R.; Woo, S.L.; Cirillo, V.; Maggio, A. Biostimulant activity of Azotobacter chroococcum and Trichoderma harzianum in Durum wheat under water and nitrogen deficiency. Agronomy 2021, 11, 380. [CrossRef]

5. Machado, D.F.M.; Parzianello, F.R.; Silva, A.C.F.; Antoniolli, Z.I. Trichoderma no Brasil: O fungo e o bioagente. Rev. Cienc. Agrar. 2012, 35, 274-288.

6. Carillo, P.; Woo, S.L.; Comite, E.; El-Nakhel, C.; Rouphael, Y.; Fusco, G.M.; Borzacchiello, A.; Lanzuise, S.; Vinale, F. Application of Trichoderma harzianum, 6-Pentyl- $\alpha$-pyrone and plant biopolymer formulations modulate plant metabolism and fruit quality of plum tomatoes. Plants 2020, 9, 771. [CrossRef] [PubMed]

7. Halifu, S.; Deng, X.; Song, X.; Song, R.; Liang, X. Inhibitory mechanism of Trichoderma virens ZT05 on Rhizoctonia solani. Plants 2020, 9, 912. [CrossRef] [PubMed]

8. Marra, R.; Coppola, M.; Pironti, A.; Grasso, F.; Lombardi, N.; d’Errico, G.; Sicari, A.; Bolletti Censi, S.; Woo, S.L.; Rao, R.; et al. The Application of Trichoderma strains or metabolites alters the olive leaf metabolome and the expression of defense-related genes. J. Fungi 2020, 6, 369. [CrossRef]

9. Chitiva-Chitiva, L.C.; Ladino-Vargas, C.; Cuca-Suárez, L.E.; Prieto-Rodríguez, J.A.; Patiño-Ladino, O.J. Antifungal activity of chemical constituents from Piper pesaresanum C. DC. and derivatives against phytopathogen fungi of cocoa. Molecules 2021, 26, 3256. [CrossRef] [PubMed]

10. Piasentin, F.B.; Saito, C.H. Os diferentes métodos de cultivo de cacau no sudeste da Bahia, Brasil: Aspectos históricos e percepções. Bol. Mus. Para. Emílio Goeldi. Ciências Hum. 2014, 9, 61-78. [CrossRef]

11. Cilas, C.; Bastide, P. Challenges to cocoa production in the face of climate change and the spread of pests and diseases. Agronomy 2020, 10, 1232. [CrossRef]

12. Rodrigues, G.S.; Magalhães, D.M.A.; Costa, A.M.; Luz, E.D.M.N. Antagonismo de Trichoderma spp. ao agente etiológico da murcha de Ceratocystis em cacaueiro. Summa Phytopathol. 2018, 44, 72-78. [CrossRef]

13. Bae, A.; Sicher, R.C.; Kim, M.S.; Kim, S.H.; Strem, M.D.; Melnick, R.L.; Bailey, B.A. The beneficial endophyte Trichoderma hamatum isolate DIS 219b promotes growth and delays the onset of the drought response in Theobroma cacao. J. Exp. Bot. 2009, 60, 3279-3295. [CrossRef]

14. Lazarotto, M.; Muniz, M.F.B.; Beltrame, R.; Santos, A.F.; Mezzomo, R.P.G.; Blume, E. Qualidade fisiológica e tratamentos de sementes de Cedrela fissilis procedentes do sul do Brasil. Rev. Árvore 2013, 37, 201-210. [CrossRef]

15. Cruz, C.A.F.; Paiva, H.N.; Gomes, K.C.O.; Guerrero, C.R.A. Efeito de diferentes níveis de saturação por bases no desenvolvimento e qualidade de mudas de ipê roxo (Tabebuia impetiginosa (Mart.) Standley). Sci. For. 2004, 66, 100-107.

16. Venial, L.R.; Alexandre, R.S.; Camata, H.; Lopes, J.C.; Zanotti, R.F.; Ferreira, A.; Aguilar, M.A.G. Biometria e armazenamento de sementes de genótipos de cacaueiro. Pesqui. Florest. Bras. 2017, 37, 39-46. [CrossRef]

17. Argout, X.; Salse, J.; Aury, J.-M.; Guiltinan, M.J.; Droc, G.; Gouzy, J.; Allegre, M.; Chaparro, C.; Legavre, T.; Maximova, S.N.; et al. The genome of Theobroma cacao. Nat. Genet. 2011, 43, 101-108. [CrossRef]

18. Salles, B.P.A.; David, A.M.S.S.; Figueiredo, J.C.; Maia, V.M.; Prudêncio, J.R.S.; Pereira, K.K.G. Viabilidade de sementes de cacau e limitações no armazenamento. Rev. Cienc. Agrar. 2019, 42, 1010-1014. [CrossRef]

19. Lum, M.R.; Hirsch, A.M. Rots and their symbiotic microbes: Strategies to obtain nitrogen and phosphorus in a nutrient limiting environment. J. Plant Growth Regul. 2003, 21, 368-382. [CrossRef]

20. Khalid, A.; Arsha, M.; Zahir, Z.A. Screening plant growth-promoting rhizobacteria for improving growth and yield of wheat. J. Appl. Microbiol. 2004, 96, 473-480. [CrossRef]

21. Gutiérrez-Luna, F.M.; López-Bucio, J.; Altamirano-Hernández, J.; Valencia-Cantero, E.; de la Cruz, E.R.; Macías-Rodríguez, L. Plant growth-promoting rhizobacteria modulate root-system architecture in Arabidopsis thaliana through volatile organic compound emission. Symbiosis 2010, 51, 75-83. [CrossRef]

22. Germida, J.J.; Walley, F.L. Plant growth-promoting rhizobacteria alter rooting patterns and arbuscular mycorrhizal fungi colonization of field-grown spring wheat. Biol. Fertil. Soils 1996, 23, 113-120. [CrossRef]

23. Orhan, E.; Esitken, A.; Ercisli, S.; Turan, M.; Sahin, F. Effects of plant growth promoting rhizobacteria (PGPR) on yield, growth and nutrient contents in organically growing raspberry. Sci. Hortic. 2006, 111, 38-43. [CrossRef]

24. Oliveira, A.G.; Chagas Junior, A.F.; Santos, G.R.; Miller, L.O.; Chagas, L.F.B. Potencial de solubilização de fosfato e produção de AIA por Trichoderma spp. Rev. Verde De Agroecol. E Desenvolv. Sustentável 2012, 7, 149-155. [CrossRef]

25. Almança, M.A.K. Aspectos da interação Arroz-Trichoderma spp. em solos alagados. Ph.D. Thesis, Universidade Federal do Rio Grande do Sul, Porto Alegre, Brazil, 2008. 
26. Santos, M.F.; Costa, D.L.; Matos, J.C.N.; Silva, G.B.; Vieira, T.A.; Lustosa, D.C. Tratamento biológico de sementes de cupuaçu para o controle de fitopatógenos e promoção da germinação. Cad. Agroecol. 2018, 13, 1017.

27. Sánchez-Hervás, M.; Gil, J.V.; Bisbal, F.; Ramón, D.; Martínez-Culebras, P.V. Mycobiota and mycotoxin producing fungi from cocoa beans. Int. J. Food Microbiol. 2008, 125, 336-340. [CrossRef]

28. Paixão, M.V.S.; Demuner, F.M.; Rodrigues, P.S.; Faria Junior, H.P.; Bozetti, M. Tratamentos pré germinativos na germinação de sementes de cacau. Int. J. Adv. Eng. Res. Sci. 2019, 6, 130-134. [CrossRef]

29. Machado, D.F.M.; Tavares, A.P.; Lopes, S.J.; Silva, A.C.F. Trichoderma spp. na emergência e crescimento de mudas de cambará (Gochnatia polymorpha (Less.) Cabrera)1. Rev. Árvore 2015, 39, 167-176. [CrossRef]

30. Lee, S.; Hung, R.; Yap, M.; Bennett, J.W. Age matters: The effects of volatile organic compounds emitted by Trichoderma atroviride on plant growth. Arch. Microbiol. 2015, 197, 723-727. [CrossRef]

31. Nieto-Jacobo, M.F.; Steyaert, J.M.; Salazar-Badillo, F.B.; Nguyen, D.V.; Rostás, M.; Braithwaite, M.; De Souza, J.T.; Jimenez-Bremont, J.F.; Ohkura, M.; Stewart, A.; et al. Environmental growth conditions of Trichoderma spp. affects Indole Acetic Acid derivatives, volatile organic compounds, and plant growth promotion. Front. Plant Sci. 2017, 9, 102. [CrossRef]

32. Hoyos-Carvajal, L.; Orduz, S.; Bissett, J. Growth stimulation in bean (Phaseolus vulgaris L.) by Trichoderma. Biol. Control 2009, 51, 409-416. [CrossRef]

33. Garnica-Vergara, A.; Barrera-Ortiz, S.; Muñoz-Parra, E.; Raya-González, J.; Méndez-Bravo, A.; Macias-Rodriguez, L.; RuizHerrera, L.F.; López-Bucio, J. The volatile 6-pentyl-2H-pyran-2-one from Trichoderma atroviride regulates Arabidopsis thaliana root morphogenesis via auxin signaling and ETHYLENE INSENSITIVE 2 functioning. New Phytol. 2015, 209, 1496-1512. [CrossRef]

34. Martins, C.Y.S. Promoção de crescimento e colonização radicular por Trichoderma spp. em pinhão manso (Jatropha curcas 1.) e mamoneira (Ricinus communis 1.). Master's Thesis, Universidade Federal do Recôncavo da Bahia, Cruz das Almas, Brazil, 2010.

35. Santos, M.F.; Santos, L.E.; Costa, D.L.; Vieira, T.A.; Lustosa, D.C. Trichoderma spp. on treatment of Handroanthus serratifolius seeds: Effect on seedling germination and development. Heliyon 2020, 6, e04044. [CrossRef] [PubMed]

36. Lustosa, D.C.; Araujo, A.J.C.; Campos, B.F.; Vieira, T.A. Trichoderma spp. and its effects on seeds physiological quality and seedlings development of African mahogany. Rev. Bras. De Cienc. Agrar. 2020, 15, 1-7. [CrossRef]

37. Azevedo, G.B.; Novaes, Q.S.; Azevedo, G.T.O.S.; Silva, H.F.; Rocha Sobrinho, G.G.; Novaes, A.B. Efeito de Trichoderma spp. no crescimento de mudas clonais de Eucalyptus camaldulensis. Sci. For. 2017, 45, 343-352. [CrossRef]

38. Chávez, D.; Pereira, G.; Machuca, A. Estimulación del crecimiento en plántulas de Pinus radiata utilizando hongos ectomicorrícicos y saprobios como biofertilizantes. Bosque 2014, 35, 57-63. [CrossRef]

39. Spaepen, S.; Vanderleyden, J.; Remans, R. Indole-3-acetic acid in microbial and microorganism-plant signaling. FEMS Microbiol. Rev. 2007, 31, 425-448. [CrossRef]

40. Farina, R. Diversidade de Bactérias Promotoras do Crescimento Vegetal Associadas a Cultura De Canola (Brassica napus L.) Cultivada no Cultivada no Município de Vacaria, Rio Grande do Sul. Ph.D. Thesis, Universidade Federal do Rio Grande do Sul, Porto Alegre, Brazil, 2012.

41. Aguiar, A.R.; Aguiar, D.; Tedesco, S.B.; Silva, A.C.F. Efeito de metabólitos produzidos por Trichoderma spp. sobre o índice mitótico em células das pontas de raízes de Allium cepa. Biosci. J. 2015, 31, 934-940. [CrossRef]

42. Korasick, D.A.; Enders, T.A.; Strader, L.C. Auxin biosynthesis and storage forms. J. Exp. Bot. 2013, 64, 2541-2555. [CrossRef]

43. Carvalho Filho, M.R.; Mello, S.C.M.; Santos, R.P.; Menêzes, J.E. Avaliação de Isolados de Trichoderma na Promoção de Crescimento, Produção de Ácido Indolacético In Vitro e Colonização Endofítica de Mudas de Eucalipto; Embrapa Recursos Genéticos e Biotecnologia: Brasília, Brazil, 2008.

44. Kapri, A.; Tewari, L. Potencial de solubilização de fosfato e atividade de fosfatase de Trichoderma spp. rizosférico. Braz. J. Microbiol. 2010, 41, 787-795. [CrossRef]

45. Ribas, P.P.; Rech, R.; Matsumura, A.T.S.; Sand, S.T.V.D. Potencial in vitro para solubilização de fosfato por Trichoderma spp. Rev. Bras. Biocienc. 2016, 14, 70-75. Available online: http://www.ufrgs.br/seerbio/ojs/index.php/rbb/article/view/2967/1315 (accessed on 30 August 2021).

46. Contreras-Cornejo, H.A.; Macías-Rodríguez, L.; Cortés-Penagos, C.; López-Bicio, J. Trichoderma virens, a plant beneficial fungus, enhances biomass production and promotes lateral root growth through an auxin-dependent mechanism in Arabidopsis. Plant Physiol. 2009, 149, 1579-1592. [CrossRef]

47. Santos, M.F.; Costa, D.L.; Vieira, T.A.; Lustosa, D.C. Effect of Trichoderma spp. fungus for production of seedlings in Enterolobium Schomburgkii (Benth.) Benth. Aust. J. Crop Sci. 2019, 10, 1706-1711. [CrossRef]

48. Junges, E.; Muniz, M.F.; Mezzomo, R.; Bastos, B.; Machado, R.T. Trichoderma spp. na produção de mudas de espécies florestais. Floresta Ambiente 2016, 23, 237-244. [CrossRef]

49. Bettiol, W.; Silva, J.C.; Castro, M.L.M.P. Uso atual e perspectivas do Trichoderma no Brasil. In Trichoderma-Uso na Agricultura; Meyer, M.C., Mazaro, S.M., Silva, J.C., Eds.; Embrapa: Brasília, Brazil, 2019; pp. 21-43.

50. Maguire, J.D. Speed of germination-aid in selection and evaluation for seedling emergence and vigor. Crop Sci. 1962, 2, 176-177. [CrossRef]

51. Climate-Data.org. Santarem. 2021. Available online: https://pt.climate-data.org/search/?q=santarem (accessed on 18 June 2021 ).

52. Silva, F.A.S. Assistat: Versão 7.7 Beta. Available online: http:/ / www.assistat.com (accessed on 20 May 2014). 